\title{
Does the rise of STEM education mean the demise of sustainability education?
}

Caroline Smith and Jane Watson

University of Tasmania

\begin{abstract}
In this article, we outline the key principles of Education for Sustainability (EfS), which enable us to question the enthusiastic and uncritical promotion of STEM (Science, Mathematics, Engineering and Technology) and its offshoot STEM education, as key contributors to an environmentally sustainable future. We examine the framing of STEM and STEM education as situated in an unproblematised neoliberal growthist paradigm, in contrast to the more critical ecological paradigm of EfS. We conclude that STEM and hence STEM education, need to include critical reflection and futures perspectives if they are to align themselves with a flourishing economic, social and environmental future. We provide examples for the classroom that illustrate our contention.
\end{abstract}

\section{Introduction}

This article outlines the principles underpinning Education for Sustainability (EfS) in order to contrast them with the current strong promotion of STEM (Science, Mathematics, Engineering and Technology) and hence STEM education which, we contend, threatens to undermine any progress EfS has made. We argue that prevailing views of STEM situate it, consciously or not, within a growthist techno-optimist neoliberal ideology. We contend that because STEM appears to be fundamentally aligned this way, it is inherently unable to provide the type of deep transformational education that is needed to live sustainably. Rather than the gateway to a rosy future, we suggest that STEM is in many ways, furthering an increasingly unsustainable business-as-usual future in an increasingly complex and globalised world. 
In this regard, our critique of STEM aligns with post-normal science (Funtowicz \& Ravetz, 1993). Post-normal science is regarded by its proponents as a way of doing science that deals with uncertainties, complexities, and diversity of values and beliefs, with the explicit goal of confronting and remedying the pathologies of the global industrial system, whose foundation is firmly based in current conceptualisations of science (and hence STEM) (Wesselink \& Hoppe, 2010).

\section{Education for Sustainability}

There are a number of ways of describing education for/in/about the environment. These include Environmental Education (Gillett, 1977); Education for Sustainability (Australian Government Department of the Environment, Water, Heritage and the Arts (DEWHA, 2009); Education for Sustainable Development (UNESCO, 2018), and Sustainable Education (Sterling, 2001). These various iterations and conceptualisations of education relating to the environment and sustainability, although often contested amongst themselves (see for example, Reynolds \& Cavanaugh, 2009), nevertheless have key principles in common. These principles arise from the recognition that economic growth and continued resource extraction cannot continue on a finite planet without exacerbating the already serious environmental and social disruptions that have led to the Anthropocene (Zalasiewicz, Williams, Steffen, \& Crutzen, 2010). Here we use the term "Education for Sustainability (EfS)" to encompass this range of understandings and processes that is located within a worldview and value system, and that understands Earth as an interconnected, complex, and materially finite system.

The for in EfS is deliberate in that EfS is explicitly critical, activist, and socially transformative rather than socially reproductive (Wade, 2008). Hence, EfS does not support continued technology-mediated economic growth, and is critical of the free market. Rather, it 
acknowledges that although technology has an important role to play in education, it needs to be used in the service of a wider ecological understanding, and that the continued flourishing of life cannot be achieved through technological solutions alone. We concur with the United Nations Secretary-General's Global Education First Initiative (UNESCO, 2016) that,

\footnotetext{
Education must also be relevant in answering the big questions of the day. Technological solutions, political regulation or financial instruments alone cannot achieve sustainable development. It requires transforming the way people think and act. Education must fully assume its central role in helping people to forge more just, peaceful, tolerant and inclusive societies. It must give people the understanding, skills and values they need to cooperate in resolving the interconnected challenges of the 21 st century. (para.1)
}

Drawing on processes and principles that build ecological literacy and participatory competence, for example, the Australian Government's National Action Plan for Education for Sustainability, Living Sustainably (DEWHA, 2009), EfS aims to develop the knowledge, competencies, and worldviews necessary for people to engage in creating more sustainable patterns of living that ensure flourishing for all species and the ecosystems they depend upon. The principles of EfS are:

1. Transformation and change: skills, capacity and motivation to plan and manage change towards sustainability.

2. Education for all and lifelong learning: people of all ages and backgrounds, at all stages of life, all possible learning spaces, formal and informal, in schools, workplaces, homes and communities.

3. Systems thinking: understanding connections between environmental, economic, social and political systems.

4. Envisioning a better future: a shared vision for a sustainable future. 
5. Critical thinking and reflection: reflect on challenge, personal perception, experience, world views and accepted ways of interpreting and engaging with the world.

6. Participation: providing skills to allow participation, engaging groups and individuals in sustainability.

7. Partnerships for change: partnerships to build networks and relationships, and improve communication between different sectors of society (DEWHA, 2009, p. 9).

The principles of EfS link the environmental, social, cultural, and economics spheres with an expanded emphasis on integrated and holistic thinking, futures, and ecological and social justice. They draw on systemic thinking, collaboration, ethics and values, critical thinking, and life-long learning. They actively encourage reflection and critique of the assumptions, worldviews, myths, and metaphors underpinning business-as-usual education and its contribution to unsustainability through over-consumption (Smith, 2007; Smith \& Watson, 2016). We are not convinced that education informed by STEM is able to develop these same critical perspectives as it is currently promulgated.

\section{Education for Sustainability- edged out by STEM Education?}

Despite the enormous amount of dedicated work by sustainability educators and the tireless efforts of bodies such as the Australian Association for Environmental Education (AAEE) over many years, "sustainability" remains relegated to one of three Cross-Curriculum Priorities (CCPs) in the Australian Curriculum (Australian Curriculum, Assessment and Reporting Authority [ACARA], 2017). Although the term appears 197 times in curriculum content, it has never been afforded the status of a subject in its own right. In effect, this means that no one subject body has responsibility for sustainability curriculum, rather that all subjects have 
responsibility for all three Cross-Curriculum Priorities and the depth and manner in which they are addressed.

It would seem that in some schools, compared with the heady days of the 1990s and 2000s, EfS is now all but invisible. The excellent Federally-funded Australian Sustainable Schools Initiative (AuSSI) program initiated in 2005, has been axed, and is now wholly dependent on individual state funding. EfS in various forms is flourishing in Victorian schools, with AuSSI-based programs supported by ResourceSmart, an initiative of Sustainability Victoria (Garg, 2017), and the Catholic Education Melbourne's document Education for Sustainability in the Archdiocese of Melbourne (2015). However, in Tasmania and the Northern Territory, AuSSI has disappeared altogether, although the relatively new organisation Education for Sustainability Tasmania [n.d.], a United Nations recognised Regional Centre of Expertise, is now making inroads into sustainability education in that state. The Living Sustainably (DEWHA, 2009) document itself is now only to be found in the archived material on the Department of the Environment and Energy's Sustainability Education website (Smith \& Watson, 2016). Thorne and Whitehouse (2017) have noted that more critical notions of environmental stewardship have also taken a back seat in education.

The effectiveness of EfS in schools largely remains dependent on the knowledge, interest and commitment of the individual school or even a passionate teacher champion. Currently, there is no way to determine how or even whether sustainability is taught across Australia (Garg, 2017). Garg quotes Mark Caddy, President of the AAEE, as saying that "[S] upport for a national approach on standards has slipped... And because the implementation of a CCP subject is left to the states, there is a lack of consistent policy on sustainability education" (para. 13). In 2016, in an attempt to bridge the gaps left by Living Sustainably (DEWHA, 2009), EfS 
and AuSSI, and to breathe life into the Sustainability CCP, AAEE assumed responsibility for managing a new learning resource portal for schools on behalf of the Australian Education for Sustainability Alliance (AESA, 2015-2016). Named "Getting Started with Sustainability in Schools", the portal provides a searchable database of learning resources linked to ACARA. Its success remains to be seen, but in this context it becomes all too easy to marginalise EfS when educational agendas change, teacher knowledge is not adequate, or when other priorities prevail.

\section{The rise of STEM}

The same cannot be said of STEM and its offshoot, STEM education. STEM is now increasingly and uncritically advanced as the road to innovation that will rescue us from our contemporary societal ills; Carter (2017) calls this an "innovation obsession" (p. 9). As EfS seems to fade away, STEM is seen as the means to meeting our energy and resource needs in a post-industrial low-carbon future as well as liberating us from drudgery through the creation of large amounts of knowledge-based work (Smith \& Watson, 2018).

The avid and largely uncritical promotion of STEM aligns with the recent shift towards a more fluid iteration of progress in modernity - the turbocharged, digitally mediated successor of industrial culture, sometimes referred to as hypermodernity (Smith, Fraser, \& Corbett, 2017). This version of progress is increasingly centred around and dependent on the power of science and technology, with STEM framed as the vehicle to supercharge it (Smith \& Watson, 2016). Seen through the STEM lens, the future is bright with techno-optimism. The Australian Government's most recent National Innovation and Science Agenda (NISA), links directly into this, asserting that, 
[e]xtraordinary technological change is transforming how we live, work, communicate and pursue good ideas. We need to embrace new ideas in innovation and science, and harness new sources of growth to deliver the next age of economic prosperity in Australia. (Australian Government, 2017, para. 1)

\section{STEM - a Neoliberal Project}

Beginning in the 1970s, a further sharpening of hypermodernity resulted in the economic and political framing of late capitalism into the ideology of neoliberalism. Neoliberalism's hallmark values are economic growth, consumption, efficiency, winning, increased productivity, competitiveness, risk taking and power over others, through the free market as the only regulatory mechanism. As Bauman $(1993,1995)$ has argued, in the neoliberal vision, economic growth (as measured by GDP) is constructed as the central "good," the organising goal and value that drives ethics and morality. Perhaps it is no accident then, that as this ideology tightens its grip on Australia and around the world, both government and private investment in STEM-based industries, research and education are being heavily promoted.

Carter (2016) however, contends that far from a being market mechanism free from government interference, neoliberalism is actually a direct result of deliberate government and corporate ideologically-based interventions to promote its values. Further, she argues that there has always been a reciprocal and mutually productive relationship between the economy and STEM. For Carter, STEM's many advocates may not recognise that STEM is located within a neoliberal position, nor are they aware of its problematic worldview and critiques. As she puts it,

neoliberalism is now agenda for most national governments to the exclusion of all else ... [it] is the deliberate intervention by government to encourage particular types of entrepreneurial, competitive and commercial behaviour in its citizens with the market as the regulatory mechanism. It is also the 
management of populations to cultivate individualistic, competitive, acquisitive and entrepreneurial behaviour. (p. 33)

Australia's promotion of STEM as the vehicle for promoting neoliberal values is clear. Alan Finkel, Australia's current Chief Scientist, argues that as we exist in a competitive international environment, to compete effectively, business and science need each other (Lee \& Hannam, 2015). In appointing Dr Finkel, who has strong entrepreneurial credentials, the then Prime Minister Malcolm Turnbull made it clear that:

[s]cience and innovation are at the centre of the Government's agenda and key to Australia remaining a prosperous, first world economy with a generous social welfare safety net. The Australian Government recognises the importance of science, innovation and technology to our future prosperity and economic security as a nation in a rapidly expanding and diversifying global economy ... Dr Finkel is renowned for his outstanding research, industrial and entrepreneurial achievements in Australia and overseas ... His will be a vital role in shaping Australia's economic future and leading our national conversation on science, innovation and commercialisation across the research, industry and education sectors and with the wider community. (Prime Minister of Australia, 2015, paras. 5-9)

Finkel went on to stress the importance of education to STEM (as quoted in Lee \& Hannam, 2015):

My personal experience across research, business and STEM education will guide my ability

to formulate relevant advice ... We exist in a competitive international environment and to compete effectively, business needs science, science needs business, Australia needs both.(para. 4)

We contend that in this largely uncritical, over-enthusiastic, and techno-optimist positioning of STEM, and hence STEM education, by mainstream governments and industry as the saviour of environmental decline, STEM is highly problematic. 


\section{Education in STEM}

The promotion of STEM-related subjects in education has a relatively long history. Since the "Sputnik shock" of 1957, when the United States was caught napping by the launch of the Sputnik satellite by the then Soviet Union, education in the STEM disciplines has been seen as critical for global competitiveness, and especially military prowess (Dow, 1997; Powell, 2007). In the 1960s, deliberate orientation to STEM in the education sectors of the United Kingdom and Australia, amongst others, followed the United States's lead, though the term itself was not used till 2001 by the US National Science Foundation (which originally called it SMET) (Marick Group, 2016).

The orientation to developing hi-tech industries could be seen throughout the science and mathematics curricula of the day. The chemistry curriculum was heavy with industrial processes, whereas mathematics was the mathematics of engineering and science-algebra, trigonometry, and calculus - rather than of accounting, statistics, and economics. Once the structure of DNA was understood, genetics, the precursor to biotechnology, became a major focus in biology education, whereas the focus in botany education shifted away from taxonomy and towards plant growth physiology and the importance of plant growth hormones in horticulture. Agriculture education focused on pesticides, inorganic fertilisers, intensification of production and later, genetic modification or crops, rather than on sustainable agriculture and maintaining the soil microbiome (e.g., Massey, 2017). This also reflects the experience of one of us (CS) who went through science and agriculture education during this period. In contrast, Environmental Education was not properly recognised in education until 1977, when the historic Tbilisi Declaration was framed (Gillett, 1977). By then, the swing towards the components of STEM education was well established. 
In the United States, concern was growing that schools were not properly equipping students to be STEM-literate. Under former President George W. Bush, reports from the early 2000s pointed to what was termed "the dire need" for US students to increase their proficiency in STEM disciplines. In 2009, President Obama announced the Educate to Innovate initiative, whose goal was to see US students in the top 10 countries in STEM achievement over the next 10 years. A key supporting initiative was the preparation of 100,000 new STEM teachers by 2021 through increased federal investment in STEM education (Marick Group, 2016).

In Australia, although STEM itself is not yet represented as an entity in the Australian school curriculum, an ACARA STEM Connections Project Report (2016) on the ACARA website strongly argues for it to be included, and for teachers to engage in professional learning in STEM. Hackling, Murcia, West, and Anderson (2014) draw the links between STEM and STEM education very clearly.

[E]ducation in science, technology, engineering and mathematics (STEM) is a powerful and productive driving force for economic growth. A strong STEM education system provides the essential underpinning of an innovative and scientifically literate culture that develops the capabilities for individuals to function effectively within a science and technology based society, provides an ever-widening range of career opportunities and, builds the productive capacity required to drive a prosperous economy and enhanced well-being in an increasingly competitive world. (p. 1)

At the same time, Prinsley and Johnston (2015) report that, as in the United States, in Australia not enough teachers and students have a strong background in STEM, which is placing serious constraints on the country's capacity for STEM-focused innovation and economic growth. For Prinsley and Johnston, 
[a] strong economy in the twenty-first century prospers through science, technology, engineering and mathematics (STEM). Across the world, nations are competing for the high-growth firms and highly capable workers of the future; and securing the pipelines in their education systems today. They know that children entering the education system in 2016 will be joining a very different workforce in 2030 . They see the rising premium on skills in STEM. In these nations, STEM education counts. (p. 1)

To address this shortage, a number of universities are currently appointing professors of STEM education and offering postgraduate opportunities in the field (e.g., the University of South Australia (Australasian Science Education Research Association [ASERA], 2017) and Monash University Handbook (2018).

\section{STEM and Environmental Sustainability}

All these initiatives point to the clear purpose of STEM education, that is, to prepare students for a hypermodern, techno-optimist, competitive global future: a very different future from that espoused by EfS. Hence, we argue that the current promotion of STEM in education has direct implications for EfS, and that uncritical and over-optimistic views of STEM and STEM education cannot go unchallenged. However, neoliberalism is now so entrenched globally that at times it is almost impossible to envision a different world (Smith, 2007; Smith \& Watson, 2016).

Beyond the STEM world, many writers maintain that technological solutions to our predicament are woefully inadequate to ensure a sustainable footing into the future. Stein (2016) argues that we now live in a time of such mass existential identity crisis that humanity is no longer capable of fully understanding its place in the biosphere; this identity crisis has coincided with the onset of the Anthropocene. Stein further argues we are not prepared for or even understand the responsibility imposed by the Anthropocene, where urgent, critical 
questions must be asked about the relationship between the human and the natural world. For Fenwick, Edwards, and Sawchuk (2010) and Malafouris (2013), our salvation lies in nothing less than the decentering of the sovereign human subject. In other words, a shift is needed from anthropocentricism toward a more inclusive ecocentrism where what Abram (1997) refers to as the 'more-than-human world', our ultimate life support system, is taken into account and nurtured rather than destroyed.

We agree that in its present conceptualisation as described above, STEM is unable to frame such questions, let alone provide answers that will see humanity and the more-than-human world thrive. Arising from its unexamined neoliberal worldview and the internationalisation of economies that accompany globalisation, STEM proponents still appear to assume economic growth as a given, in spite of the growing recognition of its ecological impacts on the world's ecosystems (Smith \& Watson, 2018; Thiele, 2013). The notion that our growthist economic system is incompatible with sustainability is rarely mentioned or even understood within much of the STEM community.

Where STEM does directly attempt to address sustainability concerns, generally solutions consistent with its techno-optimist discourse are actively promoted. These range from renewable energy generation and storage as a response to climate change and SMART technologies for agriculture using machine intelligence (Papuso \& Faraby, 2013), to large scale geoengineering planetary systems (Earth Talk, 2018). The concept of "Ecomodernism" advanced by the Breakthrough Institute (Asafu-Adjaye et al., 2015) signifies a major attempt to apply neoliberal values to environmental futures. Ecomodernism claims that "a good Anthropocene demands that humans use their growing social, economic, and technological powers to make life better for people, stabilise the climate, and protect the natural world" (p. 
7). However, critiques of these approaches abound; see for example Hamilton (2015), who has been particularly scathing of what he sees as the partial solutions of the Ecomodernist agenda.

Further, such proposed solutions seem blind to the reality that progress in the rich world is accompanied by misery in the poor world. For example, recent research by Wiedmann and Lenzen (2018) on the environmental and social impacts of globalisation, reveals the extent to which rich countries outsource production and waste to poor countries. They estimate that the citizens of rich countries require the work of up to five poor people per citizen to satisfy their consumption levels, while the poor bear the brunt of our large environmental and social footprints. Wiedmann and Lenzen also note the duplicity of Western politicians who at the same time claim that they are "cleaning up their act." Such actions are now coming home to roost, as China no longer accepts Australian waste.

McMillan (2017) outlines ten drivers that she considers are damaging the living world, (Table 1), while economic growth continues to be a key priority of nations (Thiele, 2013). STEM is directly implicated in half of these and indirectly in others (Smith \& Watson, 2018).

Table 1

Contribution of STEM to Drivers of Damage to the Living World

\begin{tabular}{|lc|}
\hline \multicolumn{1}{|c|}{ Driver } & $\begin{array}{c}\text { How STEM is directly } \\
\text { implicated }\end{array}$ \\
\hline Dominant neoliberal world view of free markets, individualism and & The prevailing \\
technological progress & conceptualisation of \\
& STEM is tied to a \\
& growthist worldview \\
\hline
\end{tabular}




\begin{tabular}{|c|c|}
\hline Disconnecting from and undervaluing nature & \\
\hline $\begin{array}{l}\text { The endless pursuit of economic growth through unrestrained free } \\
\text { markets and associated advertising }\end{array}$ & STEM promotes this \\
\hline Corporate marketing and overconsumption & $\begin{array}{l}\text { STEM is currently } \\
\text { mediated through free } \\
\text { markets }\end{array}$ \\
\hline $\begin{array}{l}\text { Limited accounting measures that externalise environmental damage } \\
\text { e.g., GDP }\end{array}$ & \\
\hline Media that reflect and support dominant power structures & $\begin{array}{l}\text { STEM is integrated into } \\
\text { the dominant power } \\
\text { structures }\end{array}$ \\
\hline $\begin{array}{l}\text { Discounting risks not seen as immediate, rejection of myths that seem } \\
\text { overwhelming; psychological desire to conform }\end{array}$ & \\
\hline Population growth & \\
\hline Technological advancement that amplifies human impact on nature & $\begin{array}{l}\text { STEM is heavily } \\
\text { technologically focussed }\end{array}$ \\
\hline Institutions and corporations that ignore environmental degradation & \\
\hline Limited access to environmental justice within the legal system & \\
\hline
\end{tabular}

\section{STEM Education and EfS}

Given the ecological crisis humanity and the more-than-human world is enmeshed in, one might imagine that education would play a critical and leading role in what Thomas Berry (1999) has called the Great Work - the transformation of society towards a flourishing, sustainable future. It seems, however, that in education, many students continue to experience a profound, but largely unconscious dissonance between what they hear about the state of the planet and their lived experience of education - in other words, there is an ongoing crisis of 
praxis. The underlying message transmitted through much of education, not just STEM, remains one of "do well, get a good job, and consume," and, in spite of UNESCO's decade of Education for Sustainable Development from 2005 to 2014 (UNESCO, 2005), education that explicitly addresses the ecological crisis continues to play a minor role (Smith, 2007). Other than the welcome shift towards renewable energy, in many ways, this position has not moved much from Orr's (1999) much-quoted description of education where,

[t]he Western education system, which has replaced indigenous forms of education throughout the world, prepares students almost exclusively for an urban existence and dependence on fossil fuels and global trade. Children are taught from an early age how best to compete with each other rather than how best to work towards and live in a sustainable society. (p. 166)

Although its advocates would argue that STEM education does address sustainability, we contend that while it continues to operate from a neoliberal, hi-tech growthist perspective, it has little chance of moving us towards a flourishing future. Indeed, the rise of STEM has meant that the emphasis on scientific and technological solutions is now education's main way of addressing sustainability (Davis, 2012). Illustrations of this are not difficult to find. A notable example is the STELR project (Science and Technology Education Leveraging Relevance) designed by the Australian Academy of Technological Sciences and Engineering (ATSE, 2010, 2016), a STEM-supportive organisation. STELR taps into the high level of concern that the majority of students have about climate change but bases its modules only on advancing technological solutions such as renewable energy. However, as Gasparatos, Doll, Esteban, Abubakari, and Olang (2017) point out, renewable energy alone is not the answer without reducing overall ecological footprints, and radical decisions about reducing consumption must be canvassed - a major challenge to the growthist agenda. Further, negative impacts on biodiversity need to be considered when developing renewable energy policies. Similarly, 
Bybee (2010) argues for STEM to be the engine for addressing environmental concerns, stating that, “... STEM could mean an integrated curricular approach to studying grand challenges of our era. I am referring to challenges such as: energy efficiency, resource use, environmental quality, and hazard mitigation" (p.31).

We acknowledge that not all issues encompassing sustainability can be addressed in single activities at the school level. However, there are some signs that both STEM and sustainability proponents are coming to appreciate the need to promote each other at both school and university levels across the STEM disciplines; see for example, Hopkinson and James (2010) and Pitt (2009), in the United Kingdom, and Pecen, Humston, and Yildiz (2012), and Farmer, Tank, and Moore (2015) in the United States. Currently, the authors are working with Australian primary school students to develop STEM projects that include a critical futures perspective. One example in Year 5 is seed dispersal. Here, students learn about the biology of seeds and their dispersal, then design and test different dispersal mechanisms, using a statistical package to display and discuss their data. They can also consider possible futures for seeds and learn, for example, about the importance of the Svarlbard Global Seed Vault. With older students, a more critical approach is possible where there is discussion of the impact of industrial agriculture and biotechnology on crop biodiversity, sustainability, and seed futures.

Another example of linking sustainability and STEM education is found in a classroom activity carried out with Year 5 students to determine if they and their compatriots around Australia were environmentally friendly (Watson \& English, 2015). By answering questions posed by the Australian Bureau of Statistics on its CensusAtSchool website at that time. Students made decisions in relation to water and power usage and recycling of rubbish. This required appreciation of the potential of STEM-based solutions for the reduction of waste, as well as 
skills in technology to collect random samples from a "population" of Year 5 students from the CensusAtSchool site. Although in itself an excellent example of a STEM activity, this activity did not pose the sorts of questions that could lead to critical reflection and action, which an EfS approach might do. An initial exploration that considered the causes of high water and power use and production of waste would have enabled students to think past the obvious technical solutions towards investigating consumer culture and its impact on the natural world.

\section{Inclusion of the Arts - STEAM Education}

Recent calls for the Arts to be integrated into STEM as STEAM also offer a constructive avenue for STEM to be drawn more closely to EfS. The inclusion of pedagogies drawn from the Arts enables teachers to engage in creative and critical thinking that enrich and expand the scope of STEM (Taylor, 2016; 2018). For Taylor (2016), STEAM education is not in opposition to STEM education. Rather, it provides the creative design space for teachers to collaborate in developing integrated curricula that uses the Arts as ways of exploring and expressing their understanding. As Taylor puts, it, STEAM education "involves teachers in developing a humanistic vision of 21 st century education and their role as professionals" ( $\mathrm{p}$. 92).

\section{In conclusion: Rethinking STEM for a flourishing future}

In this article, we have argued that although the disciplines of STEM are promoted as providing significant answers to the existential questions of the $21^{\text {st }}$ century with the concomitant implications for education, the hypermodern, techno-optimist worldview from which STEM emerges, especially in its neoliberal form, is deeply conflicted and presents unexamined barriers to constructive pathways to a viable future. At the same time, we recognise that STEM can and should provide critically important skills and insights into alternative futures as ways 
forward for economic, social, and environmental sustainability, as well as education, as we navigate the difficult waters of the Anthropocene.

We believe than that if STEM education is approached through the critical and sustainabilityfocused lenses of EfS, instead of contributing to the continued laying waste of Earth's ecosystems and resources, STEM can to be harnessed in the service of the flourishing of humanity and the more-than-human world. This will only be possible, however, if STEM and STEM education are explicitly broadened to include critical reflection and futures dimensions, by adopting the principles and perspectives offered by EfS, and enhanced by STEAM education. 


\section{References}

Abram, D. (1997). The spell of the sensuous: Perception and language in a more-than-human world. New York: Random House.

Academy of Technological Sciences and Engineering. (2010). Renewable Energy: The ATSE STELR Stage One Project 2010. Melbourne: Author.

Asafu-Adjaye, J., Blomqvist, S., Brand, S., Brook, B., Defries, R., Ellis, E., Foreman, C., Keith, D., Lewis, M., Lynas, M., Nordhaus, T., Pielke , R. Jnr., Pritzker, R., Roy, J., Sagoff, M., Shellenberger, M., Stone, R., \& Teague, P. (2015). An Ecomodernist Manifesto. Oaklands, CA: Breakthrough Institute. Retrieved from http://www.ecomodernism.org/manifesto-english/

Australian Academy of Technological Sciences and Engineering. (2016). About STELR. Melbourne: Author. Retrieved from http://www.stelr.org.au/aboutstelr

Australian Curriculum, Assessment and Reporting Authority. (2017). Cross-curriculum priorities: Sustainability. Sydney, NSW: ACARA. Retrieved from: https://www.australiancurriculum.edu.au/f-10-curriculum/cross-curriculumpriorities/sustainability/

Australian Curriculum, Assessment and Reporting Authority. (2016). ACARA STEM Connections

Project Report. Retrieved from https://www.australiancurriculum.edu.au/media/3220/stemconnections-report.pdf

Australian Education for Sustainability Alliance (2015-2016). Getting started with sustainability in schools. Resources portal. Retrieved from sustainabilityinschools.edu.au

Australian Government. (2017). National Innovation and Science Agenda. Canberra: Commonwealth of Australia. Retrieved from https://www.innovation.gov.au/page/agenda

Australian Government Department of the Environment Water Heritage and the Arts. (2009). Living sustainably: The Australian Government's National Action Plan for Education for Sustainability. Canberra: Commonwealth of Australia. Retrieved from http://www.environment.gov.au/system/files/resources/13887ab8-7e03-4b3e-82bb139b2205a0af/files/national-action-plan.pdf 
Australasian Science Education Research Association. (2017). Professor of STEM Education University of South Australia. Retrieved from https://www.asera.org.au/news/professor-stemeducation-university-south-australia

Bauman, Z. (1993). Postmodern ethics (Vol. 195). Oxford: Blackwell.

Bauman, Z. (1995). Life in fragments: Essays in postmodern morality. New York: Wiley.

Berry, T. (1999). The great work: Our way to the future. New York: Bell Tower.

Bybee, R. W. (2010). Advancing STEM education: A 2020 vision. Technology and Engineering Teacher, 70(1), 30-35.

Carter, L. (2016). Neoliberalism and STEM Education. Journal for Activist Science \& Technology Education, 7(1), 31-41.

Carter, L. (2017). Neoliberalism and STEM education: Some Australian policy discourse. Canadian Journal of Science, Mathematics and Technology Education, 17(4), 247-257. https://doi.org/10.1080/14926156.2017.1380868

Catholic Education Melbourne. (2015). Education for sustainability in the archdiocese of Melbourne. Melbourne: Author.

Davis, J. (2012). ESD starts where STEM stops: Integrating the social sciences into STEM. In K.-T. Lee (Ed.), 2nd International STEM in Education Conference, Beijing, China (pp. 177-183). Retrieved from http://eprints.qut.edu.au/67370/

Dow, P. (1997). Sputnik revisited: Historical perspectives on science reform. A symposium hosted by the Center for Science, Mathematics, and Engineering Education. Washington: National Academy of Sciences.

Earth Talk. (2018). Technological 'solutions' to climate change. Are any 'geoengineering' solutions viable or realistic?

Retrieved from https://www.scientificamerican.com/article/geoengineering-solutions/ Education for Sustainability Tasmania. [n.d.]. Retrieved from http://efs.tas.edu.au/

Farmer, S. A., Tank, K. M., \& Moore, T. J. (2015). Using STEM to reinforce measurement skills. Teaching Children Mathematics, 22(3), 196-199. 
Fenwick, T., Edwards, R., \& Sawchuk, P. (2011). Emerging approaches to educational research: Tracing the socio-material. New York: Routledge.

Funtowicz, S.O., \& Ravetz, J.R. (1993). Science for the post-normal age. Futures, 25, 735-55.

Garg, K. (2017, February 16). Teaching sustainability in schools haphazard, despite education priority. The Citizen. Retrieved from https://www.thecitizen.org.au/articles/teaching-sustainability-schoolshaphazard-despite-education-priority

Gasparatos, A., Doll, C.N.H., Esteban, M., Abubakari, A., \& Olang, T. A. (2017). Renewable energy and biodiversity: Implications for transitioning to a green economy. Renewable and Sustainable Energy Reviews, 70, 161-184.

Gillett, M. (1977). Tbilisi Declaration. Tbilisi, Georgia: International Conference on Environmental Education.

Hackling, M., Murcia, K., West, J., \& Anderson, K. (2014). Optimising STEM education in WA schools. Part 1: Summary report. Joondalup, WA: Edith Cowan Institute for Education Research.

Hamilton, C. (2015, April 21). The technofix is in: A critique of 'An Ecomodernist Manifesto.' [Latest news] Earth Island Journal. Retrieved from http://clivehamilton.com/the-technofix-is-in-acritique-of-an-ecomodernist-manifesto/

Hopkinson, P., \& James, P. (2010). Practical pedagogy for embedding ESD in Science, Technology, Engineering and Mathematics curricula. International Journal of Sustainability in Higher Education, 11(4), 365-379.

Lee, J., \& Hannam, P. (2015, October 27). Alan Finkel appointed Australia's next Chief Scientist. Sydney Morning Herald. Retrieved from http://www.smh.com.au/federal-politics/politicalnews/alan-finkel-appointed-next-australias-next-chief-scientist-20151026-gkitd7.html

Malafouris, L. (2013). How things shape the mind: A theory of material engagement. Cambridge, MA: The MIT Press.

Marick Group. (2016, May 16). A look at the history of STEM (and why we love it). Retrieved from http://marickgroup.com/news/2016/a-look-at-the-history-of-stem-and-why-we-love-it

Massey, C. (2017). Call of the reed warbler: A new agriculture - a new earth. Brisbane: University of Queensland Press. 
McMillan, S. (2017). What's driving our planet's destruction? Habitat, 45(2), 6-9.

Monash University Handbook. (2018). STEM education. Retrieved from http://www.monash.edu/pubs/2018handbooks/aos/stem-education/

Orr, D. (1999). Education for globalization. The Ecologist, 29(3), 166-169.

Papuso, I., \& Faraby, J. (2013). What is climate-smart agriculture? Seminar on Climate Change and Risk Management. Retrieved from http://www.slideshare.net/jimalfaraby/climate-smartagriculture-20675751

Pecen, R., Humston, J.L., \& Yildiz, F. (2012). Promoting STEM to young students by renewable energy applications. Journal of STEM Education, 13(3), 62-72.

Pitt, J. (2009). Blurring the boundaries - STEM education and education for sustainable development. Design and Technology Education: An International Journal, 14(1). Retrieved from http://ojs.lboro.ac.uk/ojs/index.php/DATE/article/view/201

Powell, A. (2007, October 11). How Sputnik changed U.S. education. Harvard Gazette. Retrieved from https://news.harvard.edu/gazette/story/2007/10/how-sputnik-changed-u-s-education/

Prime Minister of Australia. (2015). Dr Alan Finkel AO appointed as Australia's next Chief Scientist. (Media release). Retrieved from https://www.pm.gov.au/media/2015-10-27/dr-alan-finkel-aoappointed- australias-next-chief-scientist

Prinsley, R., \& Johnston, E. (2015). Transforming STEM teaching in Australian primary schools: everybody's business. Canberra: Office of the Chief Scientist. Retrieved from http://www.chiefscientist.gov.au/wp-content/uploads/Transforming-STEM-teaching_FINAL.pdf.

Reynolds, P., \& Cavanaugh, R. (2009). Sustainable education: Principles and practices. Paper submitted to the 2009 Annual Conference of the Australian Association for Research in Education. Canberra.

Smith, C. (2007). Education and society: The case for ecoliteracy. Education and Society, 25(1), 2537.

Smith, C., Fraser, S.P., \& Corbett, M. (2017). Liquid modernity, emplacement and education for the Anthropocene: Challenges for rural education in Tasmania. Australian and International Journal of Rural Education, 27(3), 196-212. 
Smith, C., \& Watson, J. (2016). STEM and Education for Sustainability (EfS): Finding common ground for a flourishing future. In M. Baguley (Ed.), Proceedings of the Annual Conference of Australian Association for Educational Research. Melbourne: AARE. Retrieved from http://www.aare.edu.au/data/2016_Conference/Full_papers/547_Caroline_Smith.pdf

Smith, C., \& Watson, J. (2018). STEM: Silver bullet for a viable future or just more flatland? Journal of Futures Studies, 22(4) 25-44.

Stein, Z. (2016). Education in the Anthropocene: Re-imagining schools in the midst of planetary transformation. Retrieved from http://www.zakstein.org/education-in-the-anthropocene-reimagining-schools-in-the-midst-of-planetary-transformation/

Sterling, S. (2001). Sustainable education: Revisioning learning and change. Totnes, UK: Green Books.

Taylor, P.C. (2016). Why is a STEAM curriculum perspective crucial to the 21 st century? ACER Research Conference. Retrieved from https://research.acer.edu.au/cgi/viewcontent.cgi?article=1299\&context=research_conference

Taylor, P.C. (2018). Enriching STEM with the arts to better prepare 21st century citizens. AIP Conference Proceedings. https://doi.org/10.1063/1.5019491

Thiele, L.P. (2013). Sustainability. Cambridge, UK: Polity Press.

Thorne, M., \& Whitehouse, H. (2017). Environmental stewardship in the Anthropocene (Part One): What have we learned from recent research in North Queensland schools adjacent to the wet tropics? Social Education, 35(1), 17-27.

UNESCO. (2005). UNESCO and sustainable development. Retrieved from http://unesdoc.unesco.org/images/0013/001393/139369e.pdf

UNESCO. (2016). Global education first initiative. Retrieved from http://www.unesco.org/new/en/gefi/priorities/global-citizenship.

UNESCO. (2018). Education for sustainable development. Retrieved from https://en.unesco.org/themes/education-sustainable-development 
Wade, R. (2008). Education for sustainability: Challenges and opportunities. In J. Coriddi (Ed.), Policy \& practice: A development education review (pp. 30-48). Dublin: Centre for Global Education.

Watson, J., \& English, L. (2015). Introducing the practice of statistics: Are we environmentally friendly? Mathematics Education Research Journal, 27, 585-613. DOI 10.1007/s13394-015-0153-

Z

Wesselink, A., \& Hoppe, R. (2010). If post-normal science is the solution, what is the problem?: The politics of activist environmental science. Science, Technology and Human Values, 36(3), 389-412.

Wiedmann, T., \& Lenzen, M. (2018). Environmental and social footprints of international trade. Nature Geoscience, 11(5), 314. DOI: 10.1038/s41561-018-0113-9

Zalasiewicz, J., Williams, M., Steffen, W., \& Crutzen, P. (2010). The new world of the Anthropocene. Environmental Science and Technology, 44(7), 2228-2231. 